\title{
Abolitionist John Brown's Treason against the Commonwealth of Virginia: A Lesson for State GOVERNMENTS ABOUT THE CULPABILITY OF NON- RESIDENTS FOR TREASON AGAINST THE STATE
}

\author{
James A. Beckman*
}

\begin{abstract}
This article analyzes the specific issue of whether an individual could be tried for treason by a State government if that individual is not a resident or citizen of that State. This issue is analyzed through the prism of the landmark case of John Brown $v$. Commonwealth of Virginia, a criminal prosecution which occurred in October 1859. Brown, a resident of New York, was convicted of treason against the Commonwealth of Virginia, insurrection, and murder after he attempted to overthrow the institution of slavery by force on October 16-18, 1859. After a prosecution and trial which occurred within a matter of weeks following Brown's crimes, Brown was executed on December 2, 1859. To this day, John Brown's trial and execution remains one of the leading examples of a State government exercising its power to enforce treason law on the State level and to execute an individual for that offense. Of course, the John Brown case had a major impact on American history, including being a significant factor in the presidential election of 1860 and an often-cited spark to the powder keg of tensions between the Northern and Southern States, which would erupt into a raging conflagration between the North and South in the American Civil War a short eighteen months later. However, in the legal realm, the Brown case is one of the leading and best-known examples of a state government exercising its authority to enforce its laws prohibiting treason against the State. The purpose of this article is not to discuss treason laws generally or even all the issues applicable to John Brown's trial in 1859. Rather, this article focuses only on the very specific issue of the culpability of a non-resident/non-citizen for treason against a State government. With the increased array of hostile actions against State governments in recent years, and criminal actors crossing state lines to commit these hostile acts, this article discusses an issue of importance to contemporary society, namely whether an individual can be prosecuted and convicted for treason by a State of which the defendant is not a citizen or resident.
\end{abstract}

\section{KEYWORDS}

treason, John Brown, issurrection, homeland security, crimes agains state

\footnotetext{
* James Beckman is a Professor of Legal Studies at the University of Central Florida (UCF), served as the Inaugural Chair of the Legal Studies Department at UCF (20112016), and previously served as a Professor of Law at the University of Tampa for eleven years (2000-2011). He has published and lectured extensively on John Brown, is a certified guide at the United States National Park in Harpers Ferry (where John Brown's "crimes" were committed) and is currently under contract and working on a reference book entitled Crimes against the State (ABC-CLIO Publishing; forthcoming 2023).
} 


\section{CONTENTS}

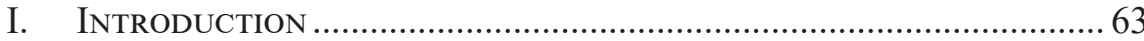

II. Confusion Among Historians on the Legitimacy of the Charge of

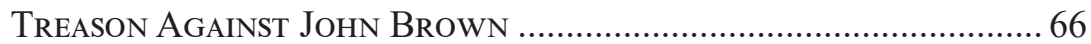

III. Basic Principles and Rules Regarding the Offense of Treason Against the Commonwealth of Virginia AND the Issue of Allegiances Owed to a State by a Non-Resident 68

IV. If Legal Residence Is Not Required to Be Charged for Treason Against a State, What Minimum Connections With a State Are Needed? Did Brown Commit Treason Under Virginia Law?..... 74 


\section{INTRODUCTION}

Can someone in the United States be tried for treason by a State government if the individual is not a resident or citizen of that State? One of the most famous treason prosecutions in United States history that occurred on the State level was the prosecution of the radical abolitionist John Brown for treason against the Commonwealth of Virginia in October 1859. ${ }^{1}$ To this day, the Brown case remains one of the most consequential cases in American history. Robert A. Ferguson, the George Edward Woodberry Professor of Law at Columbia University characterized the Brown case as one of the most telling and important cases in United States history. ${ }^{2}$ Steven Lubet, Professor of Law at Northwestern University, stated that the Brown case was "the most significant" and "consequential" in American history. ${ }^{3}$ Brown remains one of the leading examples of an individual being executed by a State government for the offense of treason. Further, the Brown case also serves as the best example of a non-resident being held accountable under the treason laws of a sister State to which he was not a resident or citizen.

In just the last several years, the country has witnessed numerous acts of violence and arguable insurrection including events such as armed protests inside the Michigan Statehouse by right wing militia members to obstruct the Michigan legislature and protest the Governor's "Stay at Home" COVID order in May 2020, ${ }^{4}$ multiple attempted seizures of the Oregon capitol and other state resources, ${ }^{5}$ a thwarted plot to kidnap Michigan Governor Gretchen Whitmer in order to overthrow the government and institute civil war in October 2020, ${ }^{6}$ and most recently, the riots and attempted insurrection at the U.S. Capitol complex on January 6, 2021.7 While the January 6, 2021, Capitol riots in Washington, DC,

1 Since the ratification of the United States Constitution, there have been only two treason prosecutions that have been completed on the state court level—one being the John Brown case and the other predating the Brown case by a decade: J. Taylor McConkie, State Treason: The History and Validity Against Individual States, 101 Ky. L.J. 281, 282, 300 (2013).

2 Robert A. Ferguson, The Trial in American Life 117-152 (2007).

3 Steven Lubet, John Brown's Trial, 52 Ala. L. Rev. 425 (Winter 2001).

4 See, e.g., Abigail Censky, Heavily Armed Protestors Gather again at Michigan Capitol to Decry Stay-At-Home Order, NPR, May 14, 2020, https://www.npr. org/2020/05/14/855918852/heavily-armed-protesters-gather-again-at-michiganscapitol-denouncing-home-order; see also, Dareh Gregorian, Calls to Violence: Michigan Gov. Whitmer Says Armed Protests Could Lengthen Stay-at-Home Orders, NBC News, May 13, 2020, https://www.nbcnews.com/politics/politics-news/calls-violencemichigan-gov-whitmer-says-armed-protests-could-lengthen-n1206296.

5 See, e.g., Azmi Haroun, Anti-Lockdown Protestors Storm Oregon Capitol Building Clashing with Police Officers, BUSINESS INSIDER, Dec. 22, 2020, https://www. businessinsId.er.com/far-right-protestors-storm-oregon-state-capitol-building-2020-12; See also, Erika Bolstad, Emboldened Far-Right Groups Challenge Cities, States, Pew Institute, https://www.pewtrusts.org/en/research-and-analysis/blogs/ stateline/2020/10/13/emboldened-far-right-groups-challenge-cities-states.

6 Robert Snell \&Melissa Nann Burke, Plans to Kidnap Whitmer, Overthrow Government Spoiled, Officials Say, The Detroit News, Oct. 9, 2020, https://www.detroitnews.com/ story/news/local/michigan/2020/10/08/feds-thwart-militia-plot-kId.nap-michigan-govgretchen-whitmer/5922301002/.

7 Alex Woodward, Pro-Trump Rioters hold Capitol under Siege as President Falsely Insists Election was Stolen from Them, INDEPENDENT, Jan. 7, 2021, at https://www. 
are outside of the purview of this article as such acts would be crimes against the Federal government, and not a State government, the incident is referenced briefly here to illustrate that over 400 participating individuals who were charged came from forty five of the fifty states. ${ }^{8}$ As of the date of this article, only Alaska, Maine, North Dakota, South Dakota and Vermont has not had a citizen prosecuted for the events which occurred on January 6, 2021. ${ }^{9}$ Indeed, in the thwarted plot to kidnap the Michigan Governor and overthrow the State government, several of the roughly fourteen indicted defendants were residents/citizens of states other than Michigan, namely a defendant from Wisconsin ${ }^{10}$ and another defendant from Delaware. ${ }^{11}$ These events have indicated that people attend the planned activities from places far and wide and often involve non-residents and non-citizens.

To the extent "out-of-state" individuals intend to "levy war" against a State government (Michigan or Oregon, for example), could a State prosecute and successfully convict those individuals for treason against that State? Along with forty-three other States, ${ }^{12}$ Michigan ${ }^{13}$ and Oregon ${ }^{14}$ (like the United States) criminalize the act of treason as a matter of state constitutional law. However, does such a law apply to a non-resident who arguably does not owe the state any allegiance or loyalty as a citizen or resident would? According to an October 2020 analysis by the PEW Institute, most states have laws that could be used to prevent armed vigilantes and right-wing militia. ${ }^{15}$ Some of these state-by-state laws are delineated in a guide entitled "Prohibiting Private Armies at Public Rallies: A Catalogue of Relevant State Constitutional and Statutory Provisions;" 16 however, charges of treason against the State are rarely, if ever, cited or considered as a viable option for the State in prosecuting malevolent actors against the State. In the span of country's history since 1789 , there have been fewer than thirty cases of individuals being prosecuted for treason, and virtually all these prosecutions occurred at the federal level. ${ }^{17}$ Mary McCord, the Legal Director of the Institute for

independent.co.uk/news/world/americas/us-politics/capitol-riots-what-happenedwashington-dc-timeline-b1783562.html.

8 Dinah Pulver et al., Capitol Riot Arrests: See Who's Been Charged Across the U.S., USA ToDAY, June 7, 2021, https://www.usatoday.com/storytelling/capitol-riot-mob-arrests/.

$9 \quad I d$.

10 Paul Egan, Wisconsin Man is $14^{\text {th }}$ to face charges in alleged Whitmere kIdnap plot, The Detroit News, Oct. 15, 2020, https://www.freep.com/story/news/local/ michigan/2020/10/15/whitmer-plot-charges-nessel/3661482001/.

11 Fox 10 (Phoenix), Delaware man accused in plot to kIdnap Michigan Government Whitmer pardoned by Gov. Carney in 2019, Oct. 9, 2020, at https://www.fox10phoenix. $\mathrm{com} /$ news/delaware-man-accused-in-plot-to-kId.nap-michigan-gov-gretchen-whitmerpardoned-by-gov-carney-in-2019.

12 McConkie, supra note 1, at 296, 320. See also McConkie, at 296, n. 95, for a complete delineation of the provisions in each of the forty-three states which criminalize treason.

13 Mich. CONST., art. I, \$22

14 OR. CONST., art. I, §24

15 Bolstad, supra note 5.

16 Prohibiting Private Armies at Public Rallies: A Catalogue of Relevant State Constitutional and Statutory Provisions, Institute for Constitutional Advocacy and Protection at Georgetown Law Center ( $3^{\mathrm{d}}$ ed., Sept. 2020).

17 Pamela J. Podger, Few Ever Charged or Convicted of Treason in U.S. History/Many Americans fought for other religious, political, cultural beliefs, SAN Francisco Chronicle, Dec. 9, 2001, at https://www.sfgate.com/crime/article/Few-ever-charged- 
Constitutional Advocacy and Protection at Georgetown Law Center has expressed the view that "States haven't been doing nearly enough and have not been taking advantage of the tools that they have."18 This lack of aggressive action by State governments comes at a time when "white supremacists represent the top and most lethal domestic terror threat to Americans" as of $2020 .^{19}$

Yet, at least forty-three states have laws criminalizing the offense of treason against the state. ${ }^{20}$ Of the forty-three states, twenty states criminalize treason by way of a constitutional provision, sixteen criminalize treason by both a constitutional provision and a state statute, and six criminalize treason solely by statute. ${ }^{21}$ Without question, the Brown case, along with one other state prosecution in 1844, has illustrated that a state prosecution for the offense of treason is a legitimate exercise of the powers of a state government. ${ }^{22}$ Further, the United States Supreme Court has never "specifically decided or discussed the validity of state treason laws." 23 It is a dormant police power that state governments may utilize to handle cases where a criminal defendant's intentions are to overthrow the existing government. More to the point of this article, even over 160 years later, the Brown case remains instructive as to the issue of the viability of treason charges against a non-resident and should be helpful in instructing prosecutors, courts and judges who might be grappling with this issue in 2021 or beyond.

Numerous books and articles have been written about John Brown and his attempt to overthrow the institution of slavery by force in October $1859 .{ }^{24}$

or-convicted-of-treason-in-U-S-2843242.php .

18 Bolstad, supra note 5, at 16.

19 Id.

20 McConkie, supra note 1, at 296, 320; for a listing of each of the 43 states with treason provisions and where each state defines treason in either its constitution or statutorily law, see McConkie, supra note 1, at 296, n. 95.

$21 \quad$ Id. at 298.

22 Id. at 314; the other notable successful State prosecution for treason is Rhode Island's prosecution of Thomas Dorr in 1844. Id. at 300-305.

23 Id.

24 While the list of John Brown related books are literally too numerous to delineate for purposes of this article, some of the leading books on John Brown and his actions are as follows: F.B. SANBorn, The Life AND LetTers of JoHn Brown (Robert Brothers) (1891); Oswald Garrison Villard, John Brown 1800-1859: A Biography Fifty Years After (1910); Richard J. Hinton, John Brown and His Men (1894); Tony Horowitz, Midnight Riding: John Brown and the Raid. That Sparked the Civil War (2011); Merrill D. Peterson, The Legend Revisited: John Brown (2002); Evan Carton, Patriotic Treason: John Brown and the Soul of America (2006); Truman Nelson, The Old Man: John Brown at Harper's Ferry (1973); W.E.B. Dubois, John Brown: A Biography (M.E. Sharpe, 1997) (1909); Richard Warch \& Jonathan Fanton, eds , John Brown (1973); Richard O. Boyer, The Legend of John Brown: A Biography and History (1973); Robert E. MCglone, John Brown's War Against Slavery (2009); Stephen B. Oates, To Purge This Land With Blood: A Biography of John Brown (1970); Louis A. Decaro, Jr., Fire From the Midst of You: A Religious Life of John Brown (2002); Jules Abels, Man on Fire: John Brown and the Cause of Liberty (1971); David. S. Reynolds, John Brown, Abolitionist, The Man Who Killed Slavery, Sparked the Civil War, and Seeded Civil Rights (2005); Laurence Greene, The Raid (1953); Bruce A. Ronda, Reading the Old Man: John Brown in American Culture (2008); NPS Office of Publications John Brown's Raid. (National Park Service History Series, 1973); 
Books ${ }^{25}$ and articles ${ }^{26}$ have also been written about certain aspects of the subsequent legal proceedings against him. This article will not re-hash the general historical facts surrounding John Brown, his "war against slavery," or his attack on the federal armory and arsenal at Harpers Ferry, Virginia, in 1859, that gave rise to his treason prosecution by the Commonwealth of Virginia. Neither will this article engage in a discussion about Brown's trial generally. This has been done previously by this author ${ }^{27}$ and others. ${ }^{28}$ Rather, this article will focus and discuss only the issue of whether residency or citizenship is required to proceed with charges of treason against an individual by a State government, using the Brown case as the primary vehicle and precedent in which to explore this issue in detail.

\section{Confusion Among Historians on the Legitimacy of THE Charge of Treason Against John Brown}

Reduced to its core, John Brown's raid on the federal armory and arsenal at Harpers Ferry, Virginia, in 1859, was designed to depose the slaveocracy element from American governance and to purge the legally sanctioned practice of slavery from the landscape of American constitutional law. Brown's intentions and goals were simple; namely, to raid the U.S. Armory and Arsenal at Harpers Ferry, Virginia, arm enslaved individuals in the area, and start a slave insurrection that Brown hoped would sweep throughout the South. As Truman Nelson noted in his book The Old Man, Brown's raid "was a Declaration of Independence from the United States [he and his followers] knew: from the tolerance of slavery as a sectional problem, from the political power of the slaveocracy, from the Dred Scott decision [stating] that blacks had no rights that white men needed to respect, and from all the built-in inequities and compromises that had encrusted and befouled the old promises." ${ }^{29}$ Often, in the rich genre of John Brown related literature and folklore, John Brown's actions are often described or referenced as treasonous with little or no legal analysis or explanation. For instance, Evan Carton's 2009 book on the life of John Brown is entitled Patriotic Treason: John Brown and the Soul of America, even though Carton does not include the term "treason" in his index or discuss the specific treason charge in any significant way in his book. Laurence Greene, in a 1953 book entitled The Raid, avoids all analysis of the charges against Brown and obscured the issue even further in his book by stating: "I am not going into all the legal mumbo-jumbo of the trial." ${ }^{30}$ And in his celebratory and still famous1909 biography of John Brown, W.E.B. Du Bois praises Brown's "treasonous" intent,

Jonathan Earle, John Brown's Raid on Harper's Ferry (2008); Brian McGinty, John Brown's Trial (2009).

25 See, e.g., Brian Mcginty, John Brown's Trial (2009).

26 See, e.g., Lubet, supra note 3; Thomas J. Fleming, The Trial of John Brown, American Heritage, 28-33, 92-100 (Aug. 1967); James Beckman, John Brown Trial of 1859 and Virginia Insanity Defense Laws Explored, Mag. Of The JefFerson Cnty. Hist. Society 45-60, (Oct. 2009).

27 Id.

28 Lubet, supra note 3; Fleming, supra note 26, at 28-33, 92-100.

29 Nelson, supra note 24, at 90.

30 GREENE, supra note 24, at 196. 
without specifically analyzing the treason charge, or why Brown committed treason against the Commonwealth of Virginia. ${ }^{31}$

More problematically, many scholars over the last 160 years have erroneously argued that John Brown could not have committed treason against the Commonwealth of Virginia because he was not a resident or citizen of Virginia. For instance, J. Reuben Sheeler, in a re-issue of Benjamin Quarles' classic book entitled Blacks on John Brown, explicitly asserts that "treason is an act committed by a resident or citizen against a state. John Brown was neither a resident nor a citizen of Virginia." 32 Additionally, in his book Fire from the Midst of You: A Religious Life of John Brown, Louis A. DeCaro, Jr. implicitly endorses this legal understanding when he remarks, "nor was it explained how a man from the State of New York could be charged with treason by a state he had invaded." 33 Renowned historian Thomas Fleming, in presumably summarizing the opening statement of one of Brown's lawyers (Lawson Botts) at trial, stated that "[a]ccording to the common law tradition in the United States, treason could be committed only by a resident against his own state. Surely no stretch of logic could make Brown a citizen of Virginia." 34

The notion that Virginia was incapable of trying a non-resident for treason was an idea that was not created out of whole cloth by scholars and authors in the decades and century following the case. Rather, the concept was introduced by Brown's lawyers themselves. A significant defense in Brown's case was that the charge of treason against Brown by the Commonwealth of Virginia was not only politically motivated, but invalid. In closing arguments to the jury, one of Brown's defense lawyers (Hiram Griswold) made the argument that scholars sympathetic to Brown would later echo, that "no man is guilty of treason, unless he be a citizen of the State or government against which the treason so alleged has been committed... Rebellion means the throwing off [of] allegiance to some constituted authority. But we maintain that this prisoner was not bound by any allegiance to this State, and could not, therefore, be guilty of rebellion against it." ${ }^{35}$ Samuel Chilton, another of Brown's lawyers, added that "the word treason is derived from a French word signifying betrayal. It means the betrayal of trust. Treason means betrayal of trust or confidence, the violation of fidelity or allegiance to the Commonwealth." ${ }^{36}$ Put simply, Brown's lawyers argued that Brown could not possibly be convicted of treason by the Commonwealth of Virginia because he was not a citizen of Virginia, had no meaningful legal ties to the State, and did not therefore breach a supposed duty of loyalty to Virginia. Brown's only conceivable treason under the circumstances (again, as the argument went) was against the Federal government, and a proper indictment and conviction for treason would only be possible if

DuBois, supra note 24, at 200-201.

J. Reuben Sheeler, John Brown: A Century Later, in Blacks on John Brown, 131 (Benjamin Quarles, ed., Da Capo Press, 2001) (1972).

33 Louis A. Decaro, Jr., Fire From The Midst of You: A Religious Life of John BROWN 268 (2002).

34 Fleming, supra note 26, at 93.

35 The Life, Trial and Execution of Capt. John Brown: Being a Full Account of the Attempted Insurrection at Harpers Ferry, Va 86 (1859); see also, McGinty, supra note 25, at 202.

36 Id. at 90. 
brought by the United States. Brown was clearly not a citizen or resident of Virginia leading up to the raid. In the years immediately preceding 1859 attack in Virginia, Brown resided most frequently in Ohio, New York, and the Kansas territory. He owned a home and his wife, and several children lived in upstate New York, and thus New York was Brown's most likely legal domicile. ${ }^{37}$ Thus, Brown's own lawyers' line of reasoning held that Brown's conviction and execution for treason by the Commonwealth of Virginia was unlawful as he owed no legal allegiance to Virginia. Further, Brown himself testified that he lacked the intent or the requisite mens rea to commit the offense alleged. At his trial, Brown remarked that he "never did intend murder or treason, or the destruction of property, or to excite or incite the slaves to rebellion, or to make insurrection." 38

\section{Basic Principles and Rules Regarding the Offense of TREASON Against THE COMMONWEALTH OF VIRGINIA AND THE IsSue of Allegiances Owed to A State by a Non-Resident}

Several questions must be posed and answered to determine the basis of Virginia's treason charge against Brown and the legitimacy or illegitimacy of his conviction as a non-resident. First: what were the classic legal elements of the offense of treason and what is their bearing on the question of whether it was - or is - legally possible to commit treason against the Commonwealth of Virginia (or any other State), as opposed to the Federal government? Second: who is specifically subject to treason laws on the federal or the State level? Third: did the evidence against Brown support a conclusion that Brown in fact violated Virginia's treason statute? That is (to preview some of Virginia's statutory language on the point) did Brown "levy war" against the Commonwealth? Did he "establish, without authority of the legislature, any government within its limits separate from the existing government?"

A proper understanding of the laws of treason at play in Brown's case, and the ultimate propriety of the court's ruling on the issue, begins with a consideration of what treason meant during the founding period of the United States. This in turn requires knowledge of the elements of earlier English legal definitions of treason that the United States retained. Historically, the charge of treason was the most serious offense that one could commit against the State. ${ }^{39}$ Its importance is reflected by the fact that it is the only criminal offense delineated in the Constitution (Article III, section 3) and by the fact that several of the most important key operative phrases of the American treason clause reflect concepts first developed by the English and found in an English statute enacted during the reign of Edward III in $1351 .{ }^{40}$ Those important operative phrases included defining treason to include a person "who do levy war" against the King or to "be adherents to the King's enemies in his realm, giving them aid and comfort" in the realm. ${ }^{41}$ Treason as "levying war" against the

\footnotetext{
Stan Cohen, John Brown: The Thundering Voice of Jehovah 125 (1999).

The Proceedings of the Court, 3 New York Herald, Nov. 3, 1859 (morning edition).

McGinty, supra note 25, at 77; see also, McConkie, supra note 1, at 281, 283; Hanauer v. Doane, 79 U.S. 342, 347 (1870) ("No crime is greater than treason").

40 Treason Act 1351, 25 Edw. 3 Stat 5, c.2 §2 (Eng.), https://www.legislation.gov.uk/aep/ Edw3Stat5/25/2/section/II.
}

41 Id. 
United States or "... adhering to their Enemies, giving them aid and comfort" are the two sole prohibited acts in the United States Constitution pertaining to treason and clearly directly informed by the very similar wording in the English Statute of 1351. James Wilson, the framer most frequently credited with the crafting of the treason clause in Article III, said in 1790 (referring to the English Statute of 1351 on treason), that the legal offense of treason in the United States was intentionally "transcribed from a part of the statute of Edward the third" so that the American understanding of the offense would be influenced "by the mature experience, and ascertained by the legal interpretation, of numerous revolving centuries." 42

Wilson advocated that any subsequent American application of treason law be based upon the wording of the Statute of 1351, explaining that the 1351 treason law was "like a rock, strong by nature, and fortified...," and "impregnable by all the rude and boisterous assaults, which have been made upon it, at different quarters, by ministers and judges; and as an object of national security, as well as of national pride, it may well be styled the legal Gibraltar of England." ${ }^{43}$ Wilson's insistence on interpreting American treason law consistent with English common law was subsequently endorsed by Chief Justice John Marshall, and as late as 1945, by the majority opinion of the United States Supreme Court. ${ }^{44}$ Thus, even at the outset of the American constitutional journey in 1789, the law of treason had been maturing and ripening in English Common Law for over four centuries. Its elements and requirements were established and uncontroversial long before Brown's trial in 1859.

According to the text of Article III, section 3, clause 1, of the U.S. Constitution, "treason against the United States, shall consist only in levying war against them, or in adhering to their enemies, giving them aid and comfort. No person shall be convicted of treason unless on the testimony of two witnesses to the same overt act, or on confession in open court." 45 Similarly, a decade earlier in drafting a colonial treason law in Virginia in 1776, the Virginia Assembly emulated the same 1351 statute and its application in subsequent English case law. The Virginia Assembly enacted a treason prohibition which stated that

[w] hereas divers opinions may be what case shall be adjudged treason, and what not," the General Assembly stipulated, "[t]hat if a man do levy war against this commonwealth in the same, or be adherent to the enemies of the commonwealth within the same, giving to them aid and comfort in the commonwealth or elsewhere, and thereof be legally convicted of open deed by the evidence of two sufficient and lawful witnesses, or their own voluntary confession, the cases above rehearsed shall be judged treason, which extendeth to the commonwealth. ${ }^{46}$

42 James Wilson, Of Crimes, Immediately Against the Community, in Works OF JAMES WiLson, 663-665 (Robert Green McCloskey ed., 1967).

$43 \quad I d$. at 664.

44 Cramer v. United States, 325 U.S. 1, 18 (1945).

45 U.S. CONST. art. III, §3.

46 An Act Declaring What Shall Be Treason, Laws of Virginia (1776), The Founders' Constitution, (U. Chi. P.) https://press-pubs.uchicago.edu/founders/documents/a3_3_12s11.html (last accessed on June 10, 2021). 
As is apparent, the elements and requirements between Article III of the U.S. Constitution and the Virginia Law of Treason of 1776 are almost identical in substance - not surprisingly, as both sources were copying the well-established English legal precedent from 1351.

After the Revolution, the Constitution of the Commonwealth of Virginia did not contain a treason clause. Rather, the authorities of the Commonwealth of Virginia opted to define the offense of treason through statutory law, as it had done previously in 1776 . However, by 1803 , Virginia had expanded the definition of treason beyond that of the 1351 English statute or Article III of the United States Constitution to also consist in the

erecting or establishing or causing or procuring to be erected or established, any government separate from, or independent of the government of Virginia, within the limits thereof, unless by act of the legislature of this commonwealth for that purpose first obtained; or in holding or executing under any such usurped government any office legislative, executive, judiciary, or ministerial, by whatever name such office may be distinguished, or called; or in swearing or otherwise solemnly professing allegiance or fidelity to the same; or, under pretext of authority derived from or protection afforded by such usurped government, in resisting or opposing the due execution of the laws of this commonwealth. ${ }^{47}$

Thus, the Virginia Code of 1849 (the statute in effect at the time of Brown's trial in 1859) defined treason as including any of the following acts: "(1) Levying war against the Commonwealth; (2) Adhering to its enemies, giving them aid and comfort; (3) Establishing, without authority of the legislature, any government within its limits separate from the existing government; (4) Holding or executing, in such usurped government, any office, or professing allegiance or fidelity to it; or (5) Resisting the execution of the laws under color of its authority." 48

Thus, the viability of the offense of treason against the Commonwealth of Virginia was well established in Virginia statutory and case law leading up to Brown's trial. Further, the offense of treason is not a criminal charge within the exclusive domain of the Federal government (i.e., the charge of treason is not the exclusive jurisdiction of the Federal government). The charge of treason, like many criminal offenses, allows for the possibility of concurrent jurisdiction. That is, assuming a defendant has "levied war" or otherwise met the definition of treason on the State level as well as against the federal government, that person could therefore be prosecuted by either the state or federal government, or both. The "double jeopardy" clause ("[no person shall] be subject for the same offense to be twice put in jeopardy of life or limb") of the Fifth Amendment to the United States Constitution does not attach or apply to charges or prosecutions by separate sovereigns. ${ }^{49}$ As legal scholar Brian McGinty has asserted, "Governor Wise himself recognized that the federal government could properly exercise jurisdiction over Brown" after Virginia

\footnotetext{
47 St. George Tucker, Concerning Treason, in Blackstone's CommentaRies: With Notes of Reference, Appendix, Note B (William Young Birch \& Abraham Small, 1803).

48 McGinTy, supra note 25, at 80.

49 Bartkus v. Illinois, 359 U.S. 121 (1959).
} 
had completed its proceedings..$^{50}$ On October 26, 1859, Governor Wise apparently told the New York Herald: "I told the officers of the United States that they might have the bodies of the prisoners after Virginia tribunals were done with them." 51 Concurrent jurisdiction for treason was indeed contemplated and agreed upon by a majority of the framers of the Federal Constitution, despite the views of a minority number of members. ${ }^{52}$ For instance, George Mason asserted that "the United States will have a qualified sovereignty only. The individual States will retain part of the Sovereignty. An act may be treason agst [sic] a particular State which is not so against the U. States." ${ }^{53}$ James Wilson indicated that treason would usually be a crime against the United States, "yet in many cases it may be otherwise." ${ }^{44}$ Oliver Ellsworth, a framer to the Constitution, a Senator, and the third Chief Justice to the United States Supreme Court, opined that "the U.S. are sovereign on one side of the line dividing the jurisdictions - the States on the other-each ought to have power to defend their respective Sovereignties." ${ }_{55}$ Finally, Roger Sherman stated that treason against both sovereigns was possible, indicating that "resistance agst [sic] the laws of the U-States as distinguished from resistance agst [sic] the laws of a particular State, forms the line." 56

Brown's lawyers did not contest the sovereignty of Virginia's courts to adjudicate cases of treason generally; instead, they argued that Brown could not be subject to Virginia's treason laws because, as they saw it, one must owe an allegiance to a sovereign State before being prosecuted for the breach of that allegiance or obligation of fidelity. ${ }^{57}$ Brown's lawyers were in essence arguing that proof of allegiance was a condition pre-requisite to the prosecution for treason. That is: there is an implicit element of allegiance (and breach of that duty) that must be proven in each treason case. Specifically, during the trial, Brown's lawyers argued that "no man is guilty of treason, unless he be a citizen of the State or Government against which the treason so alleged has been committed." 58 Since Brown was not a Virginian, he "was not bound by any allegiance to this State, and could not, therefore, be guilty of rebellion against it." 59 And again later in the proceedings, Brown's lawyers argued "treason could not be committed against a Commonwealth except by a citizen thereof." 60 This position was in accordance with generations of jurists going back several centuries. Most recently, in connection with the Brown trial, in the 1820 case of United States v. Wilberger, U. S. Supreme Court Chief Justice John Marshall stipulated the pre-requisites for a proper treason charge as follows: "treason is a breach of allegiance, and can be committed by him

50 McGinTY, supra note 25, at 81.

51 Speech of Governor Wise at Richmond, New York Herald, Oct. 26, 1859 (morning edition), at 1.

52 McConkie, supra note 1, at 287-289.

532 The Records of the Federal Convention of 1787347 (Max Farrand, ed. 1911).

$54 \quad I d$. at 348.

$55 \quad I d$. at 349.

56 Id.

57 The Trial of John Brown for Treason and Insurrection, Charlestown, Virginia, 1859, in 6 American States Trials 782 (Lawson, ed. 1916).

$58 \quad$ Id.

$59 \quad I d$.

$60 \quad$ Id. at 792. 
only who owes allegiance (to the sovereign) either perpetual or temporary." ${ }^{61}$ At about the same, English jurist William Blackstone explained that treason "imports a betraying, treachery, or breach of faith." ${ }^{62}$

At a minimum, the class of persons owing loyalty and obedience to the sovereign or the State comprises its citizens and residents. Citizens who breach that loyalty are subject to prosecution for treason. But the precedent set by the text and application of the 1351 treason statute--hailed in 1833 by U. S. Supreme Court Justice Joseph Story as "the polar star of English jurisprudence upon this subject" and "the well-settled interpretation of these phrases in the administration of criminal law"-_defines the subjects of allegiance more broadly. ${ }^{63}$

However, writing around 1600, Sir Edward Coke, one of England's most eminent common law jurists and legal scholars, explained: "[a]ll aliens that are within the realm of England, and whose sovereigns are in amity with the king of England, are within the protection of the king, and do owe a local obedience to the king . . . and if they commit high treason against the king, they shall be punished as traitors." ${ }^{64}$ Thus, mere presence in the realm of England, rather than actual residence, would seem to be sufficient to create a local allegiance in Coke's interpretation of the 1351 statute. In support of this view, Coke cited his own precedent in a famous common law decision entitled Calvin's Case. In the early eighteenth century, William Hawkins contended similarly that "it seems clear, that the subjects of a foreign prince coming into England and living under the protection of our king, may, in respect of that local allegiance which they owe to him, be guilty of high treason." ${ }^{65}$ Indeed, "even an ambassador committing a treason [sic] against the king's life, may be condemned and executed here." Finally, William Blackstone, an English jurist whose legal expertise and authority rivaled Coke's (and who was massively influential among American colonial jurists), simply stated that "local allegiance is such as is due from an alien, or stranger born, for so long time as he continues within the king's dominion and protection."

Additionally, the 1776 Continental Congress "Committee on Spies" Resolution offers strong evidence that the eventual framers of the United States Constitution were well aware of the above interpretations of the "allegiance" requirement for treason law (i.e., that even a temporary and passing presence in a territory could make one subject to that territory's treason laws). The "Committee on Spies" was composed of John Adams, Thomas Jefferson, John Rutledge \& Robert Livingston. The committee's resolution, obviously enacted at the onset of the Revolutionary War, specified that any person "passing through, visiting, or making a temporary

\footnotetext{
${ }_{61}$ United States v. Wilberger, 18 U.S. 76, 96 (1820) (emphasis added).

624 William Blackstone, Commentaries On The Laws Of England 74-75 (Philadelphia, Everty Duychkinck, George Long, Collins \& Co., Collins \& Hannay, \& Abraham Small, Last London ed. 1822).

63 Carlton F.W. Larson, Forgotten Constitutional Law of Treason and the Enemy Combatant Problem, 154 U. Penn. L. J. 853, 873, n. 37 (quoting JosePh Story, Commentaries on the Constitution of the United States $\S \S 1791,1793$ (1833)).

64 Id. at 875 (quoting Edward Coke, Third Part of the Institutes of the Laws of ENGLAND 2 (London, 5th ed. 1671)).

65 Id at 875-876 (quoting 1 William Hawkins, A Treatise of the Pleas of the Crown, 35 (Savoy 1716)).

66 Id. at 877 (quoting William Blackstone's COMmENTARIES ON THE LAWs OF ENGLAND).
} 
stay in any of the said colonies, being entitled to the protection of the laws during the time of such passage, visitation or temporary stay, owe, during the same time, allegiance thereto." Furthermore, according to the resolution, all persons

owing allegiance to any of the United Colonies, as before described, who shall levy war against any of the said colonies within the same, or be adherent to the king of Great Britain, or others the enemies of the said colonies, or any of them, within the same, giving to him or them aid and comfort, are guilty of treason against such colony. ${ }^{67}$

Finally, approximately only two years after the Brown case, the United States District Court in Massachusetts (in an 1861 charge to a grand jury as to the definition of treason), instructed that "every sojourner who enjoys our protection, is bound to good faith toward our government, and although an alien, he may be guilty of treason by cooperating either with rebels or foreign enemies." ${ }^{68}$ While this statement was made two years after Brown's case, it is a reflection of the common understanding of the jurists of this era in regard to treason--that treason may be committed even by those whose presence in the State is temporary.

The Commonwealth prosecutor of Brown (Andrew Hunter) focused in on the views of Coke and Blackstone delineated above, and argued that treason charges did not require citizenship. The prosecution argued that "the evidence of this case shows, without a shadow of a question, that when this man came to Virginia and planted his feet on Harper's Ferry, he came there to reside and hold the place permanently." 69 While there was not really solid evidence that Brown came to Virginia to "reside" or to "hold the place permanently" beyond his statement to Virginia Governor that he intended to set up a provisional government in Virginia, ${ }^{70}$ the court deemed his brief presence in Virginia to be sufficient for purposes of treason charges. Indeed, after closing statements, Brown's lawyers tried one last time, asking for a jury instruction instructing the jury that "if they believed the prisoner was not a citizen of Virginia, but of another State, that they cannot convict on a count of treason." 71 The court refused this jury instruction and Brown was convicted of treason, insurrection and murder after the jury had deliberated for about 45 minutes. $^{72}$

67 Continental Congress, Committee on Spies (5 June 1776), The Founders' Constitution, U. CHI. P., at https://press-pubs.uchicago.edu/founders/documents/a3_3_1-2s9.html (last accessed on June 10, 2021); see also, Journals of the Continental Congress, 17741776, Monday, June 24, 1776, at https://memory.loc.gov/cgi-bin/query/r?ammem/ hlaw:@field(DOCID.+@lit(jc00517)) (last accessed on July 8, 2021).

68 Charge to Grand Jury-Treason, 30 F. Cas. 1039-40 (D. Mass. 1861) (No. 18,273).

69 The Life, Trial And Execution of Capt. John Brown: Being A Full Account of the Attempted Insurrection at Harpers Ferry, Va 92; see also, 6 American States TRIALS, supra note 57 at 797.

70 See infra, note 89.

716 AMERican States Trials, supra note 57, at 799.

72 Id. at $799-800,802$. 


\section{If Legal Residence Is Not Required to Be Charged for Treason Against a State, What Minimum Connections With a State Are NeEded? Did Brown Commit Treason UNDER VIRGINIA LAW?}

Considering the above laws which clearly indicated that one could be charged with treason even if the charged individual was not a resident or citizen of the State, then what sufficient ties will suffice against a non-resident? The facts of the Brown case are instructive as to this issue. Beyond Brown's appearance in Virginia to conduct his raid from October 16-18, 1859, there is good evidence that Brown visited Virginia multiple times between July and October 1859- thus subjecting himself to the laws and protections of the Commonwealth during those visits. Exactly how many times Brown visited or passed through Virginia during this period is still subject to debate. However, at a minimum, many John Brown sources indicate that Brown arrived at the train depot in Harpers Ferry, Virginia, in early July 1859 , before crossing over the Potomac River to find shelter at Sandy Hook, Maryland. ${ }^{73}$ Brown had also purchased "picks and shovels in Harpers Ferry" (ostensibly to contribute to his cover story, that he was a mineral prospector) in July $1859 .^{74}$ In a summary of Brown's insurrection and trial published immediately after the events in 1859, it is indicated that Brown "bought a large number of picks and spades, that this confirmed the belief that they intended to mine for ores. They were frequently seen in and about Harper's Ferry, but no suspicion seems to have existed that 'Bill Smith' was Capt. Brown, or that he intended embarking in any movement so desperate or extraordinary." 75 In a subsequent inquiry by the United States Senate six months later, John Allstadt was called as a witness and asked if he had ever seen Brown before his attack on Harpers Ferry in October. Allstadt responded as follows:

I had seen him at Harper's Ferry, on the street; and I had seen him also at the cars [rail station] when the cars would land there; I inquired who he was; he was walking up and down; he was a stranger to me, and I asked who that old gentleman was; they told me his name was Smith; I recognized him when we got to the Armory yard as being that Smith, but they called him Brown then. ${ }^{76}$

And then when asked when and how often Allstadt had seen Brown prior to his attack in October, Allstadt responded that he "had seen him at different times, perhaps a month before that, and perhaps I saw him not two weeks before that; I do not recollect exactly; I saw him at different times." ${ }^{\prime 77}$ The Senate report also contained

\footnotetext{
73 See, e.g., Mason Report, Select Committee of the Senate of the United States on the Harpers Ferry Invasion, June 15, 1860, at 5; ABELS, supra note 26; OATES, supra note 24, at 275); LuBET, supra note 3, at 48.

74 ABELS, supra note 24, at 242.

75 The Life, Trial and ExeCution of CAPT. John Brown, supra note 69 at 9.

76 Mason Report, Select Committee of the Senate of the United States on the Harpers Ferry Invasion, June 15,1860 , at 42 .

77 Id.
} 
numerous documents and letters from Brown, including a letter dated June 30, 1859, where he wrote in part that he was to "leave today for Harper's Ferry...you can write I. Smith \& Sons, at Harpers Ferry, should you need to do so." ${ }^{, 78}$ Another townsperson (Wager House clerk W.W. Throckmorton) gave a sworn statement indicating that, again during the late summer, he remembered seeing Brown at the train depot in Harpers Ferry, awaiting the arrival of trains. Jules Abels, in his 1971 book on Brown entitled Man on Fire, states that Brown was seen frequently in Harpers Ferry where he purchased "picks and shovels in Harpers Ferry" and received boxes from the train depot which Brown claimed contained mining equipment. ${ }^{79}$ Additionally, in fellow-raider John Cook's printed confession, Cook indicates that he met John Brown in the streets of Harpers Ferry, Virginia, outside Tearney's store on Shenandoah Street in downtown Harpers Ferry, in late summer 1859 (i.e., late July or early August). ${ }^{80}$ Law Professor Steven Lubet has described Brown's trips to Harpers Ferry, Virginia, as both frequent and conspicuous: "[H]e traveled freely around the area... he made a point of reconnoitering Harpers Ferry in person, familiarizing himself with the layout of the streets, bridges, trestles, as well as the locations and entranceways of important buildings... [and] the two men boldly met in broad daylight on Shenandoah Street in the center of Harpers Ferry." ${ }^{11}$

At Brown's trial, at least two witnesses testified that they recognized Brown as the same man they had previously seen in town. Another eyewitness to the event wrote that Brown had bought a horse "from a Harper's Ferry horse trader." 82 Further, in his famous post-Civil War era book, I Rode with Stonewall, Henry Kyd Douglas recalls an incident in which he helped a man (whom he realized, after the raid, to have been Brown) to get his stuck wagon out of the mud. This incident occurred "outside" of Shepherdstown, Virginia, "at the foot of the hill which rises from the [Potomac] river." 83 Brown traveled extensively in late July and early August and very likely passed through points in Virginia on his way to Chambersburg, Pennsylvania, and elsewhere, as he did in the incident with Henry Kid Douglas. Any of these incidents, or some combination of them, would be sufficient to show Brown's temporary presence in Virginia at various times from July through October 1859. And if Brown was in Virginia temporarily, benefiting from the protection of Virginia laws, even if not residing there, he was arguably also bound by Virginia's laws (including its treason law)_ "allegiance and protection being reciprocal," as one of Brown's lawyers put it.

At the time of Brown's trial, there seems to have been very little debate outside of court among lawyers (North or South) about the possibility of whether an alien could nonetheless be convicted of treason by a State "foreign" to the alien. Indeed, most lawyers seemed to have taken this proposition for granted. For instance, on the day of Brown's execution on December 2, 1859, Abraham Lincoln gave a speech in Troy, Kansas, condemning the Harpers Ferry raid. While Lincoln's condemnation of Brown is commonly referenced, his emphasis on the crime of treason against a

Id. at 71 .

Abels, supra note 24, at 242.

Richard J. Hinton, 2 John Brown And His Men 705 (1894).

LUBET, supra note 3, at 53 (2012).

Joseph Barry, Strange Story of Harpers Ferry 71 (The Shepherdstown Register) (1994) (1903)

83 Henry Kyde Douglass, I Rode With Stonewall 2 (U. N. Ca. P.) (1969) (1940) 
State and on the propriety of the verdict is particularly relevant here: "Old Brown has been executed for treason against a State. We cannot object, even though he agreed with us in thinking slavery wrong. That cannot excuse violence, bloodshed, and treason." ${ }^{84}$ William Seward, another prominent lawyer and legislator, soon to be Lincoln's Secretary of State, commented that all good citizens would agree "that this attempt to execute an unlawful purpose in Virginia by invasion, involving servile war, was an act of sedition and treason, and criminal in just the extent that it affected the public peace and was destructive of human happiness and life." 85

Finally, there are strong arguments, summarized by Brian McGinty in his book, John Brown's Trial, that Brown owed allegiance to Virginia based upon the Privileges and Immunities Clause of the U.S. Constitution (Article IV, sec. 2), which provides that "the citizens of each state shall be entitled to all privileges and immunities of citizens in the several states." The Clause, in essence, sets forth the requirement that a citizen of one State who goes to another State enjoys the same protections (privileges and immunities) in that second State as that second State affords to its own citizens. Virginia prosecutor Andrew Hunter attempted to articulate this concept when he said in court:

Brown came here with the immunities given by the Constitution. He did not come divested of the responsibilities belonging to those immunities. Let the word treason mean breach of trust, and did he not betray that trust with which, as a citizen, he is invested when within our borders? By the Federal Constitution, he was a citizen when he was here, and did that bond of Union--which may ultimately prove a bad bond to us in the South--allow him to come into the bosom of the Commonwealth, with the deadly purpose of applying the torch to our buildings and shedding the blood of our citizens? ${ }^{86}$

The fact that two of the black raiders who were tried (Shields Green \& John Copeland) were not ultimately convicted of treason - because they were not citizens of the United States under the infamous Dred Scott v. Sanford ruling-reinforces McGinty's argument.

The most damning evidence of Brown's treasonous intent and his guilt as far as treason was concerned, as defined by Virginia's treason statute, lay not in any act of violence that he committed between October 16-18, 1859, but rather in a document that he authored eighteen months earlier. As most Brown scholars are aware, Brown's "Provisional Constitution and Ordinances for the People of the United States" (drafted partially in the home of Frederick Douglas in February of 1858) was roughly modeled on the U.S. Constitution, which it sought to reform by excising - indeed criminalizing and rendering subject to extreme penaltiesthe institution of slavery. Brown's Provisional Constitution, a blueprint for the organization and governance of his followers if their abolitionist enterprise should last, was read to all his men on Sunday morning, October 16, 1859, immediately

\footnotetext{
84 Oswald Garrison Villard, John Brown 1800-1859: A Biography Fifty Years AFTER 564 (Houghton Mifflin) (1910) (emphasis added).

85 Id.

86 The Life, Trial And Execution of Capt. John Brown: supra note 69, at 3.
} 
preceding the raid. As described by Truman Nelson, "it was a Declaration of Independence from the United States they knew." 87

Brown's Provisional Constitution was submitted as evidence in Brown's trial and the Preamble, along with Articles 7, 45, and 48, were read into the record. ${ }^{88}$ Article 48 directed that all persons associated with Brown's Provisional Constitution should take an oath of allegiance to the newly constituted government. While Article 46 of Brown's Constitution specified that it was not designed to overthrow the U.S. Government or State governments, the document nonetheless established a competing government designed by Brown, with offices and officers (including Brown as Commander in Chief, John Kagi as Secretary of War, etc.). ${ }^{89}$ When Brown was asked by Governor Wise on October 17, 1859, where he intended to set up his "provisional government," Brown responded "here, in Virginia, where I commenced operations." 90 This statement not only lent strength to the argument that Brown intended to stay in Virginia for some time and was not merely a transitory character, but also that he violated a very peculiar aspect of Virginia's treason statute (as explained directly below).

Under Virginia's treason statute, "establishing, without authority of the legislature, any government within its limits separate from the existing government; ... or [h]olding or executing, in such usurped government, any office, or professing allegiance or fidelity to it" constituted treason. ${ }^{91}$ The prosecutor Andrew Hunter very persuasively argued as follows:

The prisoner had attempted to break down the existing Government of the Commonwealth, and establish on its ruins a new Government: he had usurped the office of Commander-in Chief of this new government, and, together with his whole band, professed allegiance and fidelity to it; he represented not only the civil authorities of the state, but his own military; he is doubly, trebly and quadruply [sic] guilty of treason. ${ }^{92}$

Brown's lawyers weakly argued that his Provisional Constitution represented a "social club" of sorts, a claim obviously belied by the revolutionary purposes that it articulated and actions that it underwrote. Brown's lawyer (Griswold) tried to explain away the treasonous Provisional Constitution as a harmless "pamphlet"93 that encouraged comradery akin to a "debating society." argued

Nelson, supra note 24, at 90.

Id. at 220.

For a complete copy of John Brown's "Provisional Constitution for the People of the United States," see Mason's Report, Select Committee of the Senate of the United States on the Harpers Ferry Invasion, June 15, 1860, at 48-59.

90 Andrew Hunter, Testimony of Andrew Hunter before the Senate Select Committee on Harper's Ferry, January 13, 1860, Masons Report. Washington, DC, 1860 at 61.

91 Virginia Code of 1849, chap. 190, $\$ 1$.

92 The Life, Trial And Execution of Capt. John Brown, supra note 69.

93 Id. at 86.

94 Id. 
how many harmless organizations have existed in the world at various times, surrounded with all the outside forms and machinery of government! Aye, even as harmless things as debating societies have been so organized, congresses created, resolutions and laws discussed, and anyone reading the bulletins and reports issued from time to time from these associations would say, why here is a miniature government within the very limits of our state. ${ }^{95}$

Brown's other lawyer (Chilton) was equally unconvincing, describing the Provisional Constitution as creating "an association or copartnership....it did not contemplate a Government, but merely a voluntary association to abolish Slavery." ${ }^{\circ 6}$ A plain reading of this document makes clear that Brown intended to create a new government devoid of slavery, with himself named as Commander-in-Chief, and with other offices and even a Congress.

The other aspect of Brown's criminal culpability for treason came in his "levying war" against the Commonwealth. What constitutes "levying war?" James Wilson, relying quite heavily on English jurists like Coke and Blackstone, defined "levying war" as including any of the following actions:

[i]nsurrections in order to throw down all inclosures, to open all prisons, to enhance the price of all labour, to expel foreigners in general, or those from any single nation living under the protection of government, to alter the established law, or to render it ineffectual-insurrections to accomplish these ends, by numbers and an open and armed force, are a levying of war against the United States. ${ }^{97}$

In addition to establishing an unauthorized government within Virginia, holding office under this new government, and taking an oath of fidelity to it, Brown also "levied war" against the Commonwealth in several of the senses stipulated above. Indeed, the whole point of Brown's raid was to render the law of slavery in Virginia "ineffectual" and thus to "alter the established law." Based on this evidence, Brown was guilty of the crime of treason, as defined by Virginia.

However, it is interesting to briefly consider whether Brown himself considered his actions to be treasonous against the Commonwealth of Virginia. At his trial, Brown remarked that he "never did intend murder or treason, or the destruction of property, or to excite or incite the slaves to rebellion, or to make insurrection." 98 This comment by Brown seems disingenuous, as the whole point of the Brown's attack on Harpers Ferry was to spirit away the enslaved from bondage, and violence was certainly foreseeable. Indeed, Brown told one of his major financial supporters that if he were successful in his southern plans, "the whole country from the Potomac to Savannah would be ablaze." 99 Phrased another way, while his primary motivation may not have been to commit "murder" or "treason," he certainly intended actions where "murder" and/or "treason" were quite foreseeable. Additionally, at least
Id.
Id. at 90 .
Wilson, supra note 42, at 668 (emphasis added).
Proceedings of the Court, New York Herald, Nov. 3, 1859 (morning edition) at 3.
OATES, supra note 24 , at 48. 
one of Brown's hostages testified that Brown acknowledged that his actions were treasonous while he was still under siege by U.S. forces while holed-up in the Armory Engine House on October 17, 1859. Ironically, this witness, John E.P. Daingerfield, was called by Brown's lawyers as a defense witness in the case and was not called as part of the Commonwealth's case against Brown. As part of his testimony, Daingerfield recounted a conversation that he overheard just before the Engine House was assaulted by the U.S. Marines. During this conversation, according to Daingerfield's sworn testimony, Brown was asked by one his men if they were "committing treason," to which Brown answered in the affirmative. ${ }^{100}$ There is no recorded objection by Brown to Daingerfield's comments in court.

Further, in 1885, Daingerfield wrote an article about his experiences during John Brown's raid, from the perspective of one of the hostages. In the article, which was published in June 1885 by The Century magazine, Daingerfield recounted the story of a conversation he had with Brown on the eve of the storming of the Engine House by U.S. Marines (the one to which he testified in October 1859):

During the night I had a long talk with Brown and told him that he and his men were committing treason against the State and the United States. Two of his men, hearing the conversation, said to their leader, 'Are we committing treason against our country by being here?' Brown answered 'Certainly.' Both said, 'If that is so, we don't want to fight anymore. We thought we came to liberate the slaves, and did not know that was committing treason.' ${ }^{101}$

If the conversation did take place as told by Daingerfield, then it shows that Brown realized that he was committing a treasonous act, not only against the United States, but also against the Commonwealth of Virginia.

As illustrated above, contrary to the many accusations of legal errors in Brown's case, his indictment and conviction for treason were sound. Brown had a temporary presence in Virginia prior to his raid, and he consequently breached his duty of allegiance by both attempting to form an illegitimate government within the Commonwealth, as well as "levying war" against it. Thus, the chief lesson of Brown's case that is still pertinent today is obvious: One does not need to be a citizen or resident for treason laws to apply; only a stay of a temporary nature or minimum contacts with the State is required. This means that the most serious criminal offense that a State may levy against an accused--the crime of treason-may be utilized against those who silently enter a territory for purposes of levying war or crimes against the State--even if the individual is not a citizen or resident of the State.

100 The Fourth Day's Proceedings, New York Herald, Oct. 31, 1859, at 1 (emphasis added).

101 John E.P. Daingerfield, John Brown at Harpers Ferry: The Fight at the Engine House, as Seen by One of His Prisoners, in The Century 265-267 (1885). 